Ann. Biol. anim. Bioch. Biophys., I975, 15 (2), 375-382.

\title{
INDUCTION OF ESTRUS, OVULATION AND FERTILITY IN PREPUBERAL GILTS
}

\author{
R. D. BAKER and B. R. DOWNEY \\ Macdonald Embryo Unit, \\ Macdonald College of McGill University, \\ Ste Anne de Bellevue, Quebec (Canada) HOA 1 CO
}

SUMMARY

Induction of synchronized estrus and ovulation in prepuberal gilts is utilized in our laboratory to study factors influencing fertility and early embryonic development. Prepuberal females provide an inexpensive source of fertilized eggs, and they are not complicated by the presence of estrous cycles. Thus, estrus inducing treatments can be applied at any time.

In the first of four experiments reported here, a single injection of $5 \mathrm{mg}$ gonadotrophin releasing hormone (GnRH) was not effective in causing either estrus or ovulation. In the second study, a single injection of either 5 or $10 \mathrm{mg} \mathrm{GnRH}$ in combination with 300 IU pregnant mare's serum gonadotrophin (PMSG) resulted in ovulation in less than $50 \mathrm{p}$. I00 of gilts treated. The dose of GnRH had no influence on the number of females ovulating or on ovulation rate.

When gilts were given an injection of $200,300,400$ or 500 IU PMSG in combination with either 200 or 300 IU human chorionic gonadotrophin (HCG), ovulation occurred in 95 p. Ioo of 80 animals treated. Laparotomies in 16 females ( 2 per group) indicated that most ovulations took place between IIO and I 20 hours after the injection regardless of the dose. All gilts were slaughtered seven days after the injection and three days after insemination. Fewer $(\mathrm{P}<\mathrm{o}$.oI $)$ ovulations were observed in gilts injected with 200 IU PMSG than with other doses of PMSG and fewer $(\mathrm{P}<0.05)$ fertilized eggs were recovered from gilts injected with $200 \mathrm{IU}$ than with either 300 or 400 IU PMSG. Ovulation rate $(\mathrm{P}<0.05)$ and ovarian weight $(\mathrm{P}<0.0 \mathrm{I})$ were increased, but uterine weight $(\mathrm{P}<\mathrm{o.oI}$ ) was reduced when the dose of HCG was increased from 200 to 300 IU. Mean maximal number of fertilized eggs ( 20 per gilt) was recovered from females injected with 400 IU PMSG plus 300 IU HCG.

In the final experiment, implants or single injections $(40 \mathrm{mg})$ of ethinyl estradiol resulted in estrus and ovulation in a majority of the females treated, but fertility was not assessed. Further research is needed to define mechanisms and to detcrmine resultant pregnancy rates in estrogen and gonadotrophin treated prepuberal gilts.

\section{INTRODUCTION}

As early as I935, Casida demonstrated that ovulation could be induced in prepuberal gilts by giving multiple injections of pregnant mare's serum gonadotrophin (PMSG) or purified pituitary powder. These observations were confirmed by 
Du Mesnil, du Buisson (I954) and Dziuk and Gehlbach (I966). In ig68, Baker and CogGrins reported that the number of ovulations increased linearly between 7.2 and 45.8 as dose of PMSG was increased from 250 to 2000 IU. However, none of the gilts showed good standing estrus and fertilized eggs were recovered from only 55 p. Ioo of the treated gilts. In addition, pregnancy in these gonadotrophin treated, prepuberal gilts was terminated by regression of the corpora lutea at about 20 days of gestation (Shaw et al., I97I ; SEgal and BAKER, I973).

More recently, an injection of a synthetic gonadotrophin releasing hormone (GnRH) increased serum FSH and LH in rats (ARIMura et al., I972) and increased serum LH in prepuberal pigs (ChAKRABORTY et al., I973 and BAKER et al., I973). In the latter study, ovulation was induced by injecting I.o $\mathrm{mg}$ GnRH into gilts whose ovaries had been stimulated to form ovulable follicles by injecting PMSG.

The purpose of experiment $\mathrm{I}$ in this study was to see if a single injection of $5 \mathrm{mg}$ of GnRH would result in estrus and ovulation in prepuberal gilts. Recently, LAMORDE and STABENFELDT (I974) reported that an injection of $3 \mathrm{mg} \mathrm{GnRH}$ resulted in vulva swelling and standing estrus in prepuberal gilts within 24 hours of the injection.

Dziuk (I964) observed ovulation in $75 \mathrm{p}$. Ioo of the prepuberal gilts given a single injection containing 250 IU PMSG and 250 IU human chorionic gonadotrophin (HCG). However, this treatment did not result in the onset of normally recurring estrous cycle. More recently, a combination of 400 IU PMSG and 200 IU HCG resulted in both synchronous estrus and high fertility in prepuberal gilts (ScHILIING and CERNE, I972, and BAKER and RAJAMAHENDRAN, I973).

Injecting PMSG alone in doses of up to Iooo IU does not usually result in ovulation in prepuberal pigs weighing less than $85 \mathrm{~kg}$ (BAKER and CoGGINS, I966, and BAKER et al., I973). Whereas, the addition of 200 IU HCG to 300 or 400 IU PMSG consistently causes estrus and ovulation. The role of the $\mathrm{HCG}$ is not fully understood. It could act directly on the ovary to stimulate an increase in endogenous estrogen production or it could act by increasing the release of endogenous gonadotrophins or both. Experiment 2 was designed to see if $\mathrm{GnRH}$ could be used as a substitute for $\mathrm{HCG}$ in the PMSG/HCG combination.

Experiment 3 was designed to further investigate the influence of doses of PMSG and HCG in the PMSG/HCG combination on estrus, ovulation and ferlitization.

Since DzIUK (1964) reported that an orally active estrogen, ethinyl estradiol $(\mathrm{EE})$, resulted in estrus and ovulation in prepuberal pigs, the use of estrogens to control ovulation in pigs has received little attention. The final experiment was designed to study the potential usefulness of either estrone or $\mathrm{EE}$ given as an injection or implant.

\section{MATERIALS AND ME'THODS}

The 165 animals used in this study were Landrace or Landrace $\times$ Yorkshire, Hampshive or Duroc crossbreds. They weighed 75 to $95 \mathrm{~kg}$, were I60 to I 80 days of age, were housed in pens of four to eight, were full-fed a I 4 p. Ioo protein finishing ration and were randomly allocated to the treatment groups within each experiment.

The gilts were observed daily for estrus in the presence of a teaser boar. Signs of estrus were rated as 3 (standing heat), 2 (swollen vulva and almost standing), I (slight swelling of vulva) or o (no indication of heat). Gilts rated 2 or 3 before the experiment started were considered to have reached puberty and were excluded from treatment. 


\section{Experiment 1}

Twelve gilts were used. Six were injected intramuscularly with $5 \mathrm{mg} \mathrm{GnRH}$ (AY 2403I, Ayerst Laboratories) in $5 \mathrm{ml}$ of saline, and six were injected with $5 \mathrm{ml}$ of saline to serve as controls. Following treatment, the animals were observed twice daily for signs of estrus as described above. Seven days post treatment, all 12 gilts were killed, reproductive tracts were removed and ovaries were weighed and examined for number and size of follicles and for ovulation points. The uterine horns were dissected free of ligaments and weighed.

\section{Experiment 2}

Thirty-six gilts were assigned to one of four treatment groups : (I) 300 IU PMSG (Equinex $\mathbf{R}$, Ayerst Laboratories) plus 200 IU HCG (APLR, Ayerst Laboratories) ; (2) 300 IU PMSG alone ; (3) 300 IU PMSG plus $5 \mathrm{mg} \mathrm{GnRH}$; and (4) $300 \mathrm{IU}$ PMSG plus $10 \mathrm{mg} \mathrm{GnRH}$. All hormones were administered as a single intramuscular injection. All gilts were checked for estrus as described above and were artificially inseminated 96 hours after the injection. Care was taken to minimize the stress of insemination in those gilts not in standing estrus. All gilts were inseminated with 80 to $100 \mathrm{ml}$ of fresh, undiluted semen from a fertile boar using a rubber corkscrew tipped (Melrose) pipette. Seven days after injection, the animals were slaughtered and eggs were recovered by flushing the oviducts and uterine horns with about $20 \mathrm{ml}$ of Tyrode's solution. Ova were mounted and examined for presence of spermatozoa and stage of development using phase-contrast microscopy.

\section{Experiment 3}

Each of eighty-five gilts were given a single intramuscular injection of PMSG and HCG in one of the following combinations (IU PMSG/IU HCG) : 200/200, 200/300, 300/200, 300/300, $400 / 200,400 / 300,500 / 200$ and 500/300. At least ten females were used per treatment group. Estrus was assessed and inseminations were performed as described in experiment 2 . In addition, two gilts in each group were anesthetized (Na pentobarbital followed by halothane) and laparotomized, mid-ventrally, I I 4 to I 20 hours following the injection to assess the time of ovulation. Care was taken to minimize the handling of the ovaries and oviducts during surgery. The gilts were slaughtered seven days following the injection, reproductive tracts were removed and ova were recovered as described above.

\section{Experiment 4}

Each of the 32 gilts was assigned to one of four groups. Treatments included (r) $40 \mathrm{mg}$ of estrone given subcutaneously in $4 \mathrm{ml}$ of corn oil, (2) $40 \mathrm{mg}$ of ethinyl estradiol given subcutaneously in corn oil, (3) implants containing $200 \mathrm{mg}$ estrone, and (4) implants containing $200 \mathrm{mg}$ cthinyl estradiol. The implants were $5.5 \mathrm{~cm}$ long and were prepared from medical-grade SilasticR tubing (ID $4.7 \mathrm{~mm} \times$ OD $7.9 \mathrm{~mm}$, Dow Corning). The steroid was placed in the lumen of the tubing and both ends were closed with Silastic R Medical Adhesive (Silicone Type A, Dow Corning). The implants were inserted subcutaneously under the loose skin in the neck behind the ear.

The gilts were observed for estrus twice daily after treatment but were not inseminated. All 32 animals were anesthetized and laparotomized mid-ventrally seven days after the injection or insertion of the implant. Ovaries were examined for follicular development and for approximate time and number of ovulations. Uterine development was noted.

\section{RESULTS AND DISCUSSION}

In contrast to a recent report (LAMORDE and STABENFELDT, I974) that a single injection of $3 \mathrm{mg} \mathrm{GnRH}$ induced standing estrus and ovulation in prepuberal gilts, none of the pigs in our study that were given $5 \mathrm{mg}$ GnRH showed either standing estrus or ovulation (table I). Three females did show some vulva swelling about 36 to 48 hours after the injection, and at slaughter seven days after the injection, two 
of three gilts with a swollen vulva and one without any external signs_of estrus had follicles larger than $6 \mathrm{~mm}$. Even though the follicles were unusually large,"there was no indication that they were going to ovulate.

TABLE, I

Estrus and ovulation in prepuberal gilts following an intramuscular injection of $5 \mathrm{mg}$ gonadotrophin releasing hormone ( $\mathrm{GnRH})$

\begin{tabular}{|c|c|c|}
\hline & Control & GnRH \\
\hline Gilts treated $\ldots \ldots \ldots \ldots \ldots \ldots \ldots$ & 6 & 6 \\
\hline Gilts showing vulva swelling .... & 0 & 3 \\
\hline Gilts showing standing estrus $\ldots \ldots$ & 0 & 0 \\
\hline Gilts with Follicles $>6 \mathrm{~mm} \ldots \ldots$ & 0 & 3 \\
\hline Follicles per gilt with follicles $>6 \mathrm{~mm}$ & 0 & 7 \\
\hline Gilts ovulated $\ldots \ldots \ldots \ldots \ldots \ldots$ & 0 & 0 \\
\hline $\begin{array}{l}\text { Uterine weight }(\mathrm{g}), \text { mean } \pm \text { Standard } \\
\text { deviation } \ldots \ldots \ldots \ldots \ldots \ldots \ldots\end{array}$ & $72 \pm 16$ & $92 \pm 21$ \\
\hline
\end{tabular}

Although GnRH was shown to induce ovulation in PMSG-primed proestrus prepuberal gilts (BAKER et al., I973), the time and value of the maximum serum LH concentration varied greatly. Gilts that ovulated following the GnRH injection had a mean maximum $\mathrm{LH}$ level of $2.8 \mathrm{ng} / \mathrm{ml}$ which occurred approximately I4 hours after the injection. The authors are not aware of any published report on serum FSH concentration in prepuberal gilts following either PMSG or HCG administration. Such data would undoubtedly help to explain the effects of these hormones.

PMSG is a potent stimulator of follicular development in most mammalian species studied to date (NALBANDOV, I958). In the prepuberal pig, ovulation does not normally occur as a result of a single injection of less than $75^{\circ}$ IU PMSG (BAKER et al., I973). However, the simultaneous administration of HCG and PMSG resulted in follicular growth and ovulation when as little as I25 IU of each gonadotrophin was given (DzIUK, I964).

The role of HCG in causing ovulation when administered with PMSG is not clearly understood. BAKER and RAJAMAHENDRAN (I973) estimated that gilts given a PMSG/HCG combination required approximately 78 hours to develop follicles capable of responding to an ovulatory stimulus. Since $\mathrm{HCG}$ has a relatively short half-life in blood (PARLOW and WARD, I96I), it is unlikely that the HCG is serving as the ovulatory stimulus. A more likely possibility is that the HCG is stimulating an increase in estrogen production from the developing follicles and that the resultant endogenous $\mathrm{LH}$ release causes ovulation.

If the above hypothesis is true, it was reasoned that $\mathrm{GnRH}$ might serve as a satisfactory substitute for HCG in the PMSG/HCG combinations. Experiment 2 was conducted to test this possibility. Combining either 5 or Io $\mathrm{mg} \mathrm{GnRH}$ with 300 IU PMSG had no positive influence on estrus, ovulation or fertility. Therefore, it was concluded that 5 or Io $\mathrm{mg} \mathrm{GnRH}$, administered with PMSG, does not contribute toward follicular maturation and ovulation as does $\mathrm{HCG}$. 
Age of the animals and different batches of PMSG may account for the observation that four of nine gilts receiving only 300 IU PMSG ovulated (table 2), which is in contrast with previous reports.

TABLE 2

Estrus and ovulation in prepuberal gilts following an intramuscular injection of gonadotrophin releasing hormone ( $\mathrm{GnRH}$ ) in combination with pregnant mares serum gonadotrophin (PMSG) and PMSG with human chorionic gonadotrophin (HCG)

\begin{tabular}{|c|c|c|c|c|}
\hline & \multicolumn{3}{|c|}{ GnRH (mg) + 300 IU PMSG } & \multirow{2}{*}{$\begin{array}{r}\text { PMSG (300 IU) } \\
+ \text { HCG }(200 \mathrm{IU})\end{array}$} \\
\hline & 0 & 5 & 10 & \\
\hline Gilts treated, no. $\ldots \ldots \ldots \ldots \ldots \ldots$ & 9 & 9 & 9 & 9 \\
\hline Estrus rating, mean . . . . . . . . & 1.7 & 1.8 & 1.2 & 1.6 \\
\hline Gilts with follicles $>6 \mathrm{~mm}$, no.... & 3 & 5 & 5 & 4 \\
\hline Follicles $>6 \mathrm{~mm}$ per gilt with & & & & \\
\hline$>6 \mathrm{~mm}$ follicles, mean $\ldots \ldots \ldots$ & 1.6 & 2.0 & 1.6 & 3.5 \\
\hline Gilts ovulated, no. $\ldots \ldots \ldots \ldots \ldots$ & $l_{k}$ & 4 & 3 & 9 \\
\hline $\begin{array}{l}\text { Ovulations per gilt that ovulated, } \\
\text { mean } \ldots \ldots \ldots \ldots \ldots \ldots \ldots \ldots \ldots\end{array}$ & 8 & 6 & 9 & 15 \\
\hline Eggs recovered $(\%) \ldots \ldots \ldots \ldots \ldots$ & 90 & 73 & 70 & 86 \\
\hline Eggs fertilized $(\%) \ldots \ldots \ldots \ldots \ldots$ & 75 & 53 & 0 & 50 \\
\hline $\begin{array}{l}\text { Uterine weight }(g) \pm \text { Standard } \\
\text { deviation } \ldots \ldots \ldots \ldots \ldots \ldots \ldots\end{array}$ & $152 \pm 41$ & $144 \pm 77$ & $148 \pm 76$ & $231 \pm 74$ \\
\hline
\end{tabular}

TABLE 3

Estrus, ovulation and fertilization in prepuberal gilts treated with a combination of pregnant mare's serum gonadotrophin (PMSG) and human chorionic gonadotrophin (HCG)

\begin{tabular}{c|c|c|c|c|c|c}
\hline $\begin{array}{c}\text { Treatment } \\
\text { PMSG/HCG } \\
\text { (IU) }\end{array}$ & $\begin{array}{c}\text { Estrus } \\
\text { rating }\end{array}$ & $\begin{array}{c}\text { Gilts } \\
\text { ovulated }\end{array}$ & $\begin{array}{c}\text { Ovulations per } \\
\text { ovulated Gilt }\end{array}$ & $\begin{array}{c}\text { Recovered } \\
\text { eggs (\%) }\end{array}$ & $\begin{array}{c}\text { Fertilized } \\
\text { eggs (\%) }\end{array}$ & $\begin{array}{c}\text { Uterine } \\
\text { weight (g) }\end{array}$ \\
\cline { 2 - 5 } $200 / 200$ & 1.7 & 8 & $11 \pm 7$ & 75 & 39 & $160 \pm 64$ \\
$200 / 300$ & 1.7 & 9 & $17 \pm 13$ & 74 & 92 & $153 \pm 69$ \\
$300 / 200$ & 2.1 & 10 & $21 \pm 9$ & 81 & 60 & $193 \pm 61$ \\
$300 / 300$ & 2.4 & 10 & $30 \pm 13$ & 72 & 61 & $171 \pm 40$ \\
$400 / 200$ & 2.4 & 10 & $20 \pm 11$ & 77 & 62 & $206 \pm 77$ \\
$400 / 300$ & 2.1 & 9 & $34 \pm 15$ & 78 & 83 & $186 \pm 36$ \\
$500 / 200$ & 2.1 & 10 & $20 \pm 13$ & 68 & 43 & $240 \pm 58$ \\
$500 / 300$ & 1.9 & 10 & $29 \pm 15$ & 66 & 58 & $221 \pm 72$ \\
\hline
\end{tabular}

In experiment 3 , only 24 ( 28 p. Ioo) of the gilts came into standing estrus, although sixty ( 7 I p. IOo) developed a red and swollen vulva 36 to 72 hours following the injection. None of the gilts were in standing heat earlier than 72 hours after the 
injection nor later than ro8 hours after the injection. Of animals showing heat, six were in the $300 \mathrm{IU}$ PMSG/300 IU HCG group and five were in the $400 \mathrm{IU} \mathrm{PMSG} / 200$ IU HCG group. All other groups had three or less gilts showing standing estrus. In addition, estrus ratings were not significantly correlated with ovulation rate (table 4 ), uterine weight or the percentage of eggs fertilized.

TABLE 4

Correlation coefficients for ovulation rate with estrus, egg recovery and uterine weight in prepuberal gilts

\begin{tabular}{c|c} 
Ovulation rate with & Correlation coefficient \\
Fistrus & 0.22 \\
Follicles $>6 \mathrm{~mm}$ & 0.12 \\
liggs recovered & $0.93^{* *}$ \\
Iiertilized eggs & $0.66^{* *}$ \\
Uterine weight & 0.12
\end{tabular}

** Correlation coefficient was significantly different from zero at $\mathrm{P}>0.01$.

Of the I 6 gilts that were laparotomized between II 4 and I20 hours after injection, eight had recently ovulated, four were in the process of ovtlating and four had preovulatory follicles but had not yet begun to ovulate. One of the gilts in the latter group did not ovulate subsequent to the laparotomy, perhaps because of the surgical interference. Observations of the ovaries indicated that most of the ovulations occurred between IIo and I20 hours after the PMSG/HCG treatment.

At slaughter, data from five gilts in experiment 3 were excluded from the analysis. Based on the presence of mid-cycle corpora lutea, three females were judged to have reached puberty before the injection, one gilt had a missing left uterine horn and the fifth had an infantile genital tract. Two of the three gilts that had mid-cycle corpora lutea also had more recent corpora lutea (mean of II) which likely resulted from the treatment.

The higher dose of HCG in combination with all doses of PMSG resulted in a greater ovulation rate $(\mathrm{P}<0.05)$ and ovarian weight $(\mathrm{P}<0.0 \mathrm{I})$ but a reduced uterine weight $(\mathrm{P}<0.0 \mathrm{I})$. Since there was no evidence that the gilts ovulated earlier following the combinations containing 300 IU HCG, the authors have no explanation for the reduced uterine weight in these gilts.

Five gilts given 500 IU PMSG/300 IU HCG had more than 35 ovulations. However, the percentage of eggs recovered and the percentage of eggs fertilized were low. In four of the gilts, examination of the ovaries indicated that ovulations may have occurred over a much wider range of time (up to 48 hours) than normal.

Experiment 4 confirms an early report by DzIUK (I964) that ethinyl estradiol induces estrus and ovulation in prepuberal gilts. In this study relatively low rates of 
ovulation were observed (table 5). Pigs in Dziuk's study were given $20 \mathrm{mg}$ ethinyl estradiol orally for five days and only four corpora lutea resulted. In both studies, the gilts had a mean of approximately nine follicle.s greater than $4 \mathrm{~mm}$.

TABI,E 5

Estrus and ounlation in gilts given an injection (4o $\mathrm{mg}$ ) or silastic implant (200 $\mathrm{mg}$ ) of ethinyl estradiol or estrone

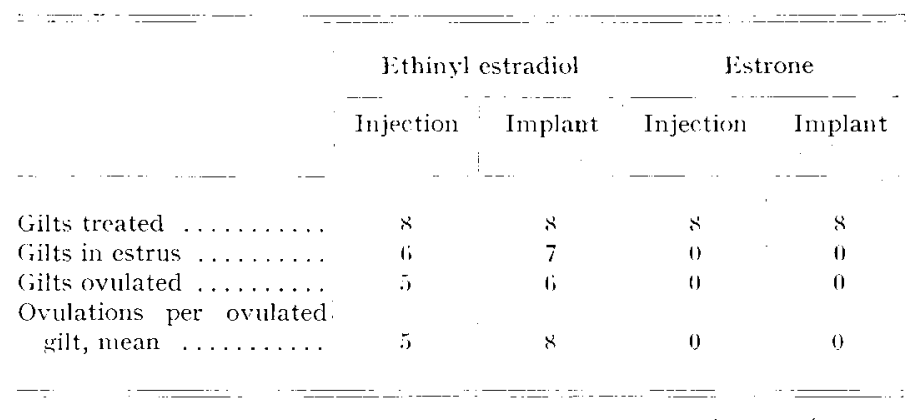

Estrone had no detectable effect on follicular development, estrus or ovulation. Uterine hypertrophy was noted in six of the gilts that were given implants, but none of the gilts that were injected.

\section{Colloque : Control of sexual cycles in domestic animals.} October $: 7-30,197.4$, Nouzilly.

\section{ACKNOWLEDGEMENTS}

The authors are grateful to George SHAw and Douglas IRvixe of Ayerst Research Laboratories for their advice and for supplying the PMSG, HCG and GnRH. Also, we want to thank Peter Conlon, Barrie Stewart and Ted Sutherlaid for their assistance in carrying out the study, and Paul LAGUË for his help in preparing the manuscript. The study was supported financially by grant no. McA-72-49 Irom the Ministère de l'. Igriculture du Québec and a grant from Ayerst Rescarch Laboratories.

\section{RÉSUMÉ}

\section{INDUCTION DE I,'GSTRUS ET DE L'OVUIATION ET FERTILITÉ CHEZ LES TRUIES IMPUBÈRES}

Nous induisons dans notre laboratoire l'estrus synchronisé et l'ovulation chez des truies impubères afin d'étudier les facteurs qui influent sur la fertilité et le développement du jeune embryon. Ia truie impubère est non seulement une source économique d'ovules fécondés mais elle est aussi libre des complications du cycle oestrien. Ainsi les traitements pour induire l'estrus peuvent être administrés à tous moments.

Dans une promière étude, $5 \mathrm{mg}$ de GnRH donnée en injection unique n'a déclanché ni l'estrus ni l'ovulation. Dans une seconde étude, après une injection unique de 5 ou ro $\mathrm{mg}$ de 
GnRH combiné avec zoo UI de l'hormone gonadotrope sérique (PMSG), nous avons observé l'ovulation dans moins de $50 \mathrm{p}$. roo des truies traitées. Le nombre de femelles ovulant et le nombre d'ovulations n'étaient pas fonction de la dose de GnRH. Nous avons cependant induit l'ovulation chez 95 p. Ioo des 80 truies que nous avions traitées avec une injection unique de 200, 300, 400, ou 500 UI de PMSG combiné avec 200 ou 300 UI de l'hormone gonadotrope chorionique (HCG). L'examen de 16 truies ( 2 par traitement) par laparotomie nous a permis de déterminer que l'ovulation avait lieu surtout entre I Io et I 20 heures après l'injection, et ceci indépendemment de la dose injectée. Toutes les truies ont été abattues sept jours après l'injection et trois jours après l'insémination. Moins $(\mathrm{P}<0.0 \mathrm{I})$ d'ovulations ont été comptées et moins $(\mathrm{P}<0.05)$ d'ovules fécondés ont été recueillis chez les truies traitées avec 200 UI de PMSG que chez celles traitées avec 300 ou 400 UI de cette hormone. Quand la dose d'HCG est passée de 200 à 300 UI, nous avons observé un taux d'ovulation plus élevé $(P<0.05)$, un plus grand poids des ovaires $(P<0.0 \mathbf{r})$ mais une diminution du poids de l'utérus $(\mathrm{P}<0.0 \mathrm{I})$. La plus haute moyenne d'ovules collectés fécondés a été observée chez les femelles traitées avec 400 UI de PMSG et 300 UI d'HCG.

Dans la quatrième et dernière étude, un implant ou une injection unique de $40 \mathrm{mg}$ d'éthinyl estradiol a provoqué l'estrus et l'ovulation chez la plupart des femelles traitées mais le taux de fertilité n'a pas été déterminé. D'autres études restent nécessaires pour définir les modes d'action et pour quantifier les taux de gestation chez les truies impubères traitées avec des estrogènes ou des gonadotropes.

\section{REFERENCES}

Arimura A., Matsuo H., Baba Y., Debeljuk L., Sandow J., Schally A. V., ig72. Stimulation of release of LH by synthetic LH-RH in vivo. I. A comparative study of natural and synthetic hormones. Endocrinol., 90, I63-168.

Baker R. D., Coggins E. G., I968. Control of ovulation rate and fertilization in prepuberal gilts. J. Anim. Sci., 27, I607-16ro.

BAKer R. D., Downey B. R., Brinkley H. J., 1973. Induction of ovulation in pigs with gonadotrophin releasing hormone. J. Anim. Sci., 39, I376-1 379 .

Baker R. D., Rajamahendran R., I973. Induction of estrus, ovulation and fertilization in prepuberal gilts by a single injection of PMSG, HCG and PMSG: HCG combination. Can. J. Anim. Sci., 53, 693-694.

Casida L. E., 1935. Prepuberal development of the pig ovary and its relations to stimulation with gonadotropie hormones. Anat. Rec., 61, 389-396.

Chakraborty P. K., Reeves J. J., Arimura A., Schally A. V., i973. Serum Lh levels in prepubertal female pigs chronically treated with synthetic luteinizing hormone-releasing hormone/follicle stimulating hormone-releasing hormone (LH-RH/FSH-RH). Endocrinol, 92, 55-6I.

Du Mesnil du Buisson F., I954. Possibilités d'ovulation et de fécondation chez la Truie avant la puberté. Ann. Endocr., 15, 333-340.

Dzurk P. J., I964. Response of sheep and swine to treatments for control of ovulation. Proc. Conference on Estrous Cycle Control in Domestic Animals. U. S. D. A. Miscellaneous publication I005, 50.

Dziuk P. J., Gehli Bach G. D., I966. Induction of ovulation and fertilization in the immature gilt. J. Anim. Sci., 25, 4 IO-4I3.

Lamorde A., Stabenfeld G. H., 1974. The sexual and ovulatory response of prepuberal gilts to gonadotrophin-releasing hormone. Proc. 7th Annual Meeting of Society for the Study of Reproduction, p. 27.

Nalbandov A. V., 1958. Reproductive Physiology, Chapter 3, P. 49-89. W. H. lireeman and Co., San Francisco.

Parlow A. F., Ward D. N., I96r. Human Pituitary Gonadotrophins p. 204-209. Thomas, Springfield, Illinois.

Schlling E., Cerne F., I972. Induction and synchronization of oestrus in prepuberal gilts and anestrus sows by a PMSG/HCG compound. Vet. Rec., 71, 471-474.

Segal D. H., Baker R. D., 1973. Maintenance of corpora lutea in prepuberal gilts. J. Anim. Sci., $39,762-767$.

Shaw G. E., McDonald B. E., Baker R. D., I97I. Fetal mortality in the prepuberal gilt. Can. J. Anim. Sci., 51, 233-236. 